\title{
STUDENTS OF SPECIAL EDUCATIONAL DISCIPLINES - ISSUE OF SOCIALIZING AND EDUCATING PEOPLE WITH HEARING IMPAIRMENT
}

\author{
Veronika Svecova \\ University of Palacky, Faculty of Education, \\ Czech Republic
}

\begin{abstract}
The contribution presents results of research which is focused on issue of socialization of people with hearing impairment. It is focused on the point of view of students of special education major. Research included 127 students of special education major who studied full time or distance study form. The questionnaire was used as research method and it included 28 opened and closed questions. The author also used Likert scale. Results showed that students of special education major prefer education of pupils with hearing impairment in the school for pupils with hearing impairment. Hearing impairment influences all areas of life - education, employment, relationships with peers, free time activities and partner relationships.
\end{abstract}

Keywords: hearing impairment; education; research; questionnaire.

\section{Introduction}

Today, the society strives to integrate people with disabilities into the major society. MacCoby (2007) defines socialization as a phenomenon when people learn values, norms and attitudes which are needed for functioning in the society. This contribution is an output of a research which was realized under the project ofIGA_PdF 2014013. The research focused on students of special education. The aim of the research was to find out how students of special education are informed about issue of socializing and educating people with hearing impairment.

\section{Theoretical basis}

Ten million people live in the Czech Republic. Czech Statistical Office has posted information that over one million of people with disabilities have lived there. This group includes people with physical impairment $(29.2 \%)$, people with visual impairment (6\%), people with hearing impairment $(5.1 \%)$, people with intellectual disabilities (6.1\%) etc. (Czech Statistical Office). The author deduces that each tenth person has some disability.360 million people with hearing impairment live around the world. This number includes 328 million adults and 32 million children (WHO, 2014).

"Hearing impairment or disability refers to the reduced function of loss of the normal function of the hearing mechanism. A person who is deaf cannot use hearing to listen, understand speech and communicate orally without special 
adaptions mainly in the visual mode. A person who is hard of hearing has a significant loss of hearing sensitivity but he or she can hear sounds, respond to speech and other auditory stimuli with or without the use of hearing aid"'(Capulong, 2007, p. 205).

The rights of the people with disabilities are regulated by the Convention on the Rights of Persons with Disabilities, published by the United Nations. This Convention wants to improve the awareness of people with disabilities (Paragraph 8), because it was found out that people with disabilities are discriminated (Convention on the Rights of Persons with Disabilities). For the period of 2010 - 2014 the National plan for creating equal opportunities for persons with disabilities was made. In the Czech Republic, people have positive attitudes towards people with disabilities but it is very important to increase the awareness of these people (Kašíková, 2010).

In the area of education is the Czech Republic supports inclusive education (Kašíková, 2010). "Inclusion refers to the placement and education of children with disabilities in regular education classrooms with children of the same age who do not have disabilities"(Dash, 2006, p. 21). All pupils are educated according to the Education Act 561/2004 Sb. The education of pupils with disabilities is adjusted by paragraph 16 . Children, pupils and student who are deaf or deafblind can be educated by communicational systems for the deaf and the deafblind. Basic education of all pupils in the Czech Republic is realized via the Framework educational programme. There are framework educational programmes for basic education, high school, pre-school education, art studies and language education (MSMT, 2015). Basic education of pupils with hearing impairment is realized according to the Framework educational program for basic education. Every school creates School educational programme, corresponding to the content of Framework educational programme for basic education. Pupils with hearing impairment belong to pupils with special needs. Pupils can be educated via the form of inclusive education (individual or group) at school for pupils with impairment or combination of these forms (MSMT, 2015). 13 basic schools for students with hearing impairment can be found in the Czech Republic (Hrubý, 1997; Švecová, 2012). A research identifying the view of the majority of special education was done of Center for Public Opinion Research in 2014. The research included 1017 responds. The results showed that pupils with hearing impairment should be educated at schools for students with hearing impairment (Červenka, 2014).

Students with hearing impairment can visit two special programmes for students with hearing impairment: Czech language in the communication of the deaf (Prague) and Educational drama of the deaf (Brno) (Komorná, 2008; Švecová, 2012). Of course, students can visit all study programmes at all universities in the Czech Republic, then they use of university counselling service. 
Similar research to the author's research was done by Vávrů (2007) who has sent a questionnaire to120 students ofMasaryk University in Brno. Vávrů identified what groups of people with disabilities the respondents would like to work with most likely. The results showed this order: 1) learning difficulties; 2) physical disability; 3) visual impairment; 4) hearing impairment; 5) intellectual disability etc.

Sedláková (2007) has also studied the attitude of the society towards people with disabilities and she has found out that the society considers intellectual disabilities as the most serious ones. In her study, the hearing impairment was on the fifth place.

Hearing impairment influences all areas of lives of people with hearing impairment (education, employment, free time, peer relationships, marriage, family etc.). Hearing impairment also influences partner relationships. The topics of partner relationships include communication, hobbies and relations of hearing and hard of hearing partner. The students suppose that people with hearing impairment think that they are disadvantaged when looking for a partner. The biggest problem is communication (Švecová, 2013). Single people with hearing prefer partner without hearing impairment or they do not have a straight forward opinion on this topic (Uhrová, 2013) and pupils with hearing impairment prefer partner without hearing impairment or they do not have a straight forward opinion on this topic (Švecová, 2013).

\section{The aim of the research}

The aim of the research was to find how students of special education are informed about hearing impairment. The area of hearing impairment is very large; it includes communication, sign language, spoken language, ethology, free time and employment, so the author focused on the socialization and education of people with hearing impairment. The area of education focused on basic questions of basic education, inclusive education, university education of hearing impairment, employment etc. The area of socialization includes the topic which informs from the point of view of the majority or the topic of partner relationships. The author thinks that benefit of this research is that it includes basic questions from different areas and these can be dealt with later in another research. In the context of the research we have formed these researched questions:

1. What are the benefits of educating pupils with hearing impairment at school for pupils with hearing impairment?

2. Which factors influence inclusive education?

3. In what areas is the hearing impairment limiting?

4. How hard is it for people with different disabilities to integrate into the society? 


\section{The target group}

The author has chosen students of special education at Palacky University, Olomouc, as her target group. The author has chosen this target group because these students of special education will meet people with hearing impairment not only during university practice but also at work. For the purpose of the research the author approached students of full time form of studies who study bachelor or master degree of special education. The author contacted these students through email addresses set up by each freshman of special education. Sadly, the author does not know the exact number of respondents asked but the last year's report stated 733 students of special education in 2013. The author received only 47 questionnaires from the students of the full time study; that is why she addressed also students of the distance study. The author did not approach student of distance form of study through email but these students filled out questionnaires during lesson. The author did not include all students of special education of distance form into the research but the lessons with the greatest number of students were chosen. The data concerning the numbers can be found in the STAG. The author would like to emphasize that research was realized between January and February and therefore the author did not address more students. Finally, the target group included 127 respondents. The research includes $96.85 \%$ females and $3.15 \%$ males. This result shows feminization in education. Equal $37 \%$ of students study present form and $63 \%$ distance form. $41.73 \%$ of students graduated from education for hearing impairment. "Tab. 1" shows basic characteristics of respondents.

Table 1. Characteristics of respondents

\begin{tabular}{|c|c|c|}
\hline & $\mathbf{n}_{\mathbf{i}}$ & $\mathbf{R}_{\mathbf{i}} \mathbf{\%}$ \\
\hline Sex & & \\
\hline female & 123 & 96,85 \\
\hline male & 4 & 3,15 \\
\hline Total & $\mathbf{1 2 7}$ & $\mathbf{1 0 0}$ \\
\hline Form of study & & \\
\hline full time & 47 & 37,00 \\
\hline distance & 80 & 63,00 \\
\hline Total & $\mathbf{1 2 7}$ & $\mathbf{1 0 0}$ \\
\hline Completion of education of hearing impaired & & 41,73 \\
\hline yes & 53 & 58,27 \\
\hline No & 74 & $\mathbf{1 0 0}$ \\
\hline Total & & \\
\hline Choosing education of hearing impaired & 127 & 29,92 \\
\hline yes & 38 & 70,08 \\
\hline To & 89 & $\mathbf{1 0 0}$ \\
\hline
\end{tabular}

(Švecová, in press) 
Legends: $\mathbf{n}_{\mathbf{i}}-$ frequency; $\mathbf{R}_{\mathbf{i}} \%-\mathrm{n}_{\mathrm{i}} / \mathbf{n}$

\section{The methodology of the research}

The author has used questionnaires to collect data. The questionnaire includes 28 questions. These questions were open-ended and closed-ended but the author has also used Likert scale. The questionnaire itself includes 5 chosen items (items 1, 2, 23, 26, 27), 3 enumeration items (items 3, 15, 18), 3 numeric scale (items 4, 12 and 20), 6 Likert scale (items 7, 10, 14, 16, 19, 21) and 11 opened items (items 5, 6, 8, 9, 11, 13, 17, 22, 24, 25, 28). The questionnaire includes two research areas: Education and Issue of socializing people with a hearing impairment. These areas were chosen for their topicality. The topic of research was education (items $1-11$ ), area of socialization (items $12-22$ ) and social demography characteristic (items $23-28$ ). Questionnaire items were set up by the author after having read publications such as Disability and the Good Human Life (Bickenbach, Felder, \& Schmitz, 2014), Psychological, Social and Educational Dimensions of Deafness (Schirmer, 2001) and Psychosocial Aspects of Deafness (Scheetz, 2004). Theauthor made the items of the questionnaire herself, because standardized questionnaire did not fit the requirements.

\section{The results of the research}

Item number one investigated which educational programme adjusts education of pupils with hearing impairment. Students chose from these options: framework educational programme general school, framework educational programme for basic education, framework educational program for hearing impairment and framework educational programme for hard of hearing and deafness. Only $26 \%$ of responds answered correctly (Framework educational programme for basic education).

Other item investigated where the pupils with a hearing impairment can be educated. The respondents chose from these questions: basic school for hearing impairment, individual integration for hearing impairment and group integration for hearing impairment. Equal $63 \%$ of responds chose possible "basic school for hearing impairment", $23 \%$ "group integration" and $14 \%$ "individual integration".

Education of pupils with hearing impairment at school for hearing impairment brings more benefits. Respondents could choose 3 possibilities at maximum. "Tab. 2" shows benefits of education of pupils with hearing impairment at school for hearing impairment. 
SOCIETY. INTEGRATION. EDUCATION. Volume III

Table 2. Benefits of education at school for hearing impairment

\begin{tabular}{|c|c|c|}
\hline Items & $\mathbf{n}_{\mathbf{i}}$ & Order \\
\hline Fewer pupils in classroom & 74 & $\mathbf{3 .}$ \\
\hline Group same impaired peers & 41 & $\mathbf{5 .}$ \\
\hline Teachers for pupils with hearing impairment & 98 & $\mathbf{1 .}$ \\
\hline Using of sign language & 55 & $\mathbf{4 .}$ \\
\hline Special educational material & 94 & $\mathbf{2 .}$ \\
\hline
\end{tabular}

Legends: $n_{l}-$ frequency

Success of integration is influenced by several factors. For example degrees of hearing loss, level of spoken language, personality of pupils with hearing impairment, lip-reading, education in pre-school with hearing children, hearing family and time of formation of hearing impairment. The influence of these factors is expressed on a numeric scale. Number 1 (depends) - 5 (does not depend). Integration depends on 1. Lip-reading (2.28); 2. Time of formation of hearing impairment (2.50); 3. Degrees of hearing loss (2.63); 4. - 5. Level of spoken language $(2.70) ; 4$. -5 . Personality ofpupils with hearing impairment (2.70); 6. Hearing family (2.74) and 7.Education in pre-school with hearing children (2.87). The results also are in "tab. 3".

Table 3. Factors of integration

\begin{tabular}{|c|c|c|c|c|c|c|c|c|c|c|c|c|}
\hline & \multicolumn{2}{|c|}{$\mathbf{1}$} & \multicolumn{2}{|c|}{$\mathbf{2}$} & \multicolumn{2}{|c|}{$\mathbf{3}$} & \multicolumn{2}{|c|}{$\mathbf{4}$} & \multicolumn{2}{|c|}{$\mathbf{5}$} & & \\
\hline & $\mathbf{n}_{\mathbf{i}}$ & $\mathbf{n}_{\mathbf{i}} \times \mathbf{1}$ & $\mathbf{n}_{\mathbf{i}}$ & $\mathbf{n}_{\mathbf{i}} \times \mathbf{2}$ & $\mathbf{n}_{\mathbf{i}}$ & $\mathbf{n}_{\mathbf{i}} \times \mathbf{3}$ & $\mathbf{n}_{\mathbf{i}}$ & $\mathbf{n}_{\mathbf{i}} \times \mathbf{4}$ & $\mathbf{n}_{\mathbf{i}}$ & $\mathbf{n}_{\mathbf{i}} \times \mathbf{5}$ & average & order \\
\hline $\mathbf{1}$ & 35 & 35 & 35 & 70 & 30 & 90 & 16 & 84 & 11 & 55 & 2.63 & $\mathbf{3 .}$ \\
\hline $\mathbf{2}$ & 19 & 19 & 43 & 86 & 32 & 96 & 19 & 76 & 14 & 70 & 2.70 & $\mathbf{4 . - 5 .}$ \\
\hline $\mathbf{3}$ & 29 & 29 & 35 & 70 & 25 & 75 & 21 & 84 & 17 & 85 & 2.70 & $\mathbf{4 . - 5 .}$ \\
\hline $\mathbf{4}$ & 20 & 20 & 49 & 58 & 32 & 96 & 15 & 60 & 11 & 55 & 2.28 & $\mathbf{1}$. \\
\hline $\mathbf{5}$ & 11 & 11 & 37 & 74 & 47 & 141 & 22 & 88 & 10 & 50 & 2.87 & $\mathbf{7}$ \\
\hline $\mathbf{6}$ & 14 & 14 & 43 & 86 & 42 & 126 & 18 & 72 & 10 & 50 & 2.74 & $\mathbf{6 .}$ \\
\hline $\mathbf{7}$ & 38 & 38 & 33 & 66 & 24 & 72 & 18 & 72 & 14 & 70 & 2.50 & $\mathbf{2 .}$ \\
\hline
\end{tabular}

Legends: 1 - degrees of hearing loss, 2 - level of spoken language, 3 - personality of pupils with hearing impairment, 4 - lip-reading, 5 - education in pre-school with hearing children, 6 - hearing family and 7 - time of formation of hearing impairment.

Students with hearing impairment can visit all universities in the Czech Republic, but only in Brno and Prague there are study programmes for students with hearing impairment. Only $11.02 \%$ of students know about these programmes.

Likert scale served to find out the degree of agreement with this statement: "People with hearing impairment have the same chance to achieve bachelor or master degrees like people without hearing impairment." Options - strongly agree, agree, neutral, disagree, and strongly disagree. $45.67 \%$ of responds strongly agree with this statement, $39.37 \%$ of responds agree, $2.36 \%$ of responds feel neutral and $12.60 \%$ of responds strongly disagree. 
Every person with disability has a different chance of integrating into the society. "Tab. 4" shows the level of integration according to students of special education. Number 1 (very light integration) - 5 (very strongly integration).

Table 4. The degree of integration of people with disability according to students

\begin{tabular}{|c|c|c|c|c|c|c|c|c|c|c|c|c|}
\hline & \multicolumn{2}{|c|}{$\mathbf{1}$} & \multicolumn{2}{|c|}{$\mathbf{2}$} & \multicolumn{2}{|c|}{$\mathbf{3}$} & \multicolumn{2}{|c|}{$\mathbf{4}$} & \multicolumn{2}{|c|}{$\mathbf{5}$} & & \\
\hline & $\mathbf{n}_{\mathbf{i}}$ & $\mathbf{n}_{\mathbf{i} \times \mathbf{1}}$ & $\mathbf{n}_{\mathbf{i}}$ & $\mathbf{n}_{\mathbf{i}} \times \mathbf{2}$ & $\mathbf{n}_{\mathbf{i}}$ & $\mathbf{n}_{\mathbf{i}} \times \mathbf{3}$ & $\mathbf{n}_{\mathbf{i}}$ & $\mathbf{n}_{\mathbf{i}} \times \mathbf{4}$ & $\mathbf{n}_{\mathbf{i}}$ & $\mathbf{n}_{\mathbf{i}} \times \mathbf{5}$ & average & order \\
\hline VI & 2 & 2 & 19 & 38 & 38 & 114 & 45 & 180 & 23 & 115 & 3.54 & $\mathbf{6 .}$ \\
\hline HI & 5 & 5 & 19 & 38 & 50 & 150 & 38 & 152 & 15 & 75 & 3.31 & $\mathbf{5}$. \\
\hline PD & 7 & 7 & 39 & 78 & 48 & 144 & 28 & 102 & 5 & 25 & 2.80 & $\mathbf{4 .}$ \\
\hline ID & 3 & 3 & 7 & 14 & 20 & 60 & 45 & 180 & 52 & 260 & 4.07 & $\mathbf{8}$. \\
\hline ASD & 1 & 1 & 12 & 24 & 29 & 87 & 35 & 140 & 50 & 250 & 3.95 & $\mathbf{7}$. \\
\hline LD & 62 & 62 & 47 & 94 & 11 & 33 & 5 & 20 & 2 & 10 & 1.72 & $\mathbf{1 .}$ \\
\hline BD & 9 & 9 & 53 & 106 & 40 & 120 & 21 & 84 & 4 & 20 & 2.67 & $\mathbf{3 .}$ \\
\hline SD & 26 & 26 & 63 & 126 & 29 & 87 & 7 & 28 & 2 & 10 & 2.18 & $\mathbf{2}$. \\
\hline
\end{tabular}

Legends: VI - visual impairment, HI - hearing impairment, PD - physical disability, ID intellectual disability, ASD - autism speech disorder, $L D$ - learning difficulties, $B D$ behavior disorders, $S D$ - speech disorder

Liker scale also found out degree of agreement with this statement: "People with hearing impairment meet different obstacles every day". $27.56 \%$ of students strongly agree with this statement, $59.06 \%$ of students agree, $11.02 \%$ of students were neutral and $2.36 \%$ of students chose to disagree.

The item finding out in which areas people with hearing impairment were limited included these options: education, employment, free time activity, parenthood, marriage, relations with peers and knowledge ability. Respondents could choose 3 items at maximum. Order of items is in "Tab. 5".

Table 5. Areas which people with hearing impairment were limited

\begin{tabular}{|c|c|}
\hline Area & $\mathbf{n}_{\mathbf{i}}$ \\
\hline Employment & 106 \\
\hline Relations with peers & 75 \\
\hline Education & 53 \\
\hline Knowledge ability & 51 \\
\hline Parenthood & 21 \\
\hline Marriage & 19 \\
\hline Free time activity & 13 \\
\hline
\end{tabular}

(Švecová, in press)

At last, Likert scale found out the degree of agreement with this statement: "People with hearing impairment are limited when choosing a partner." $7.87 \%$ of respondents chose that they strongly agreed, $47.24 \%$ of respondents agree, $21.26 \%$ of respondents choose neutral, $19.69 \%$ of disagree and $3.94 \%$ of respondents strongly disagree. Likert scale also found out the 
degree of agreement with this statement: "Partner relationship is for person with hearing impairment better with partner with hearing impairment than hearing partner." $11.02 \%$ of respondent chose that they strongly agree, 29.92 $\%$ of respondents agree, $47.67 \%$ of are neutral, $12.60 \%$ of respondents disagree and $0.79 \%$ of students strongly disagree.

\section{Conclusion}

Basic education in the Czech Republic is realized according to the Framework basic education, but the right answer was filled out by only $26 \%$ of students. The author thinks that it is very important to inform students about the issue of education because maybe they will work with children or pupils with hearing impairment.

National plan for creating equal opportunities for persons with disabilities promotes inclusive education; despite this only $27 \%$ of responds is for the inclusive education. This result is similar to results of the Center for Public Opinion Research. The Center found out that pupils with hearing and visual impairment cannot be educated through inklusive education (Červenka, 2014).

Successful integration of students with hearing impairment depends on lipreading, time of formation hearing impairment, degrees of hearing loss, level of spoken language, personality of the pupil with hearing impairment, hearing family and education in pre-school for children without disability. There are 13 basic schools for pupils with hearing impairment in Czech Republic. The authors found out these benefits of education of pupils with hearing impairment atthese schools: fewer pupils in classroom, the group of the same impaired peers, teachers for pupils with hearing impairment, using of sign language, special educational material.

The author deduces that despite of all educational activities the fear from the unknown, which comes with integration, persists. The author also believes that it is not necessary to inform the society about hearing loss but it is necessary to inform society as well as successful integration. Educational activities should be targeted primarily at parents and educators. In the Czech Republic there are two university courses for students with hearing disabilities: Czech language in the communication of the deaf and Educational Drama for the Deaf, but only $11.02 \%$ of students knows about their existence. Special education students think that people in this order (1. People with learning difficulties; 2. People with speech disorders; 3. People with behavior disorders; 4. People with physical disabilities; 5. People with hearing impairments; 6 . People with visual impairments; 7. People with autism spectrum disorders and 8. People with intellectual disabilities) integrate into the society the most easily. The author noted that similar ranking results were found in a research exploring what people with disabilities the interviewed would like to work with. 
The author concludes from the results that people without disabilities often have fear of the unknown and unexpected, because people without disabilities do not meet people with disabilities very often in society. Students from special educational disciplines believe that persons with hearing disabilities are limited when choosing a partner. These respondents also think that people with severe hearing impairment prefer persons with severe hearing impairment or do not have a strong opinion. These results are different from the results ofUhrová (2013), who found that single people with hearing impairment (regardless of the degree of hearing impairment) preferred hearing partner or they did not have a straightforward opinion on this topic and Švecová (2013) who found that pupils with hearing impairments (regardless of the degree of hearing impairment) preferred hearing people they did not have a straightforward opinion on this topic.

\section{Summary}

The contribution focused on issue of socialization of people with hearing impairment. There are presents outcomes of research which were realized on the topic: Awareness of students of special education major in the field of hearing impairment. Research included 127 students of special education major. The author thinks that this questionnaire can be used for all students and majority society. The author also believes that this questionnaire can be applied on people with hearing impairment and results can be compared. Also every questionnaire item can be elaborated into separate research.

\section{References}

Bickenbach, J. E., Felder, F., \& Schmitz, B. (2014). Disability and the Good Human Life. New York: Cambridge University Press.

Capulong, Y. T. Students with hearing impairment. In T. G. Inciong, Y. S. Quijano, \& Y. T. Capulong, Introduction to special education (202-219). Rex Book Store.

Czech Statistical Office(3 March 2015). Výběrové šetření zdravotně postižených osob 2013. Retrieved from http://www.czso.cz/csu/2014edicniplan.nsf/publ/260006-14-n_2014.

Červenka, J. (2014). Veřejnost o speciálních školách - záři 2014. Retrieved from http://cvvm.soc.cas.cz/ostatni-ruzne/verejnost-o-specialnich-skolach-zari-2014.

Dash, N. (2006). Inclusive Education for Children with Special Needs. New Delhi: Atlantic.

Hrubý, J. (1997). Průvodce světem neslyšících a nedoslýchavých po jejich vlastním osudu. Díl 1. Praha: FRSP.

Kašíková, M. (2010). Národní plán vytvárení rovných přiležitostí pro osoby se zdravotním postižením na obdobi 2010 - 2014. Úřad vlády ČR: Sekretariát Vládního výboru pro zdravotně postižené občany.

Komorná, M. (2008). Systém vzdělávání osob se sluchovým postižením v České republice. Praha : Česká komora tlumočníků znakového jazyka.

MacCoby, E. E. (2007). Historical Overview of Socialization Research and Theory. In J. E. Grusec, \& P. D. Hastings, Handbook of Socialization: Theory and Research (13-41). New York: Guilford Press.

MSMT (3 March 2015). Education Act 561/2004 Sb. (novela zákon č. 370/2012 Sb., kterým se měni zákon č. 561/2004 Sb., o předškolním, základním, středním, vyšším odborném a jiném vzděláváni (školský zákon), ve znění pozdějšich predpisü. Retrieved from http://www.msmt.cz/dokumenty/novela-skolskeho-zakona-vyklady-a-informace. 


\section{SOCIETY. INTEGRATION. EDUCATION. Volume III}

MSMT (3 March 2015). Vyhláška č. 73/2005 Sb., o vzdělávání dětí, žáků a studentů se speciálními vzdělávacími potřebami a dětí, žáků a student mimořádně nadaných novela Vyhláška č. 103/2014 Sb., kterou se měni vyhláška č. 73/2005 Sb., o vzdělávání dětí, žáků a studentů se speciálními vzdělávacími potřebami a dětí, žáki̊ a studentù mimořádně nadaných, ve zněni vyhlášky č. 147/2011 Sb. Retrieved from http://www.msmt.cz/ vzdelavani/socialni-programy/vyhlasky.

Sedláková, J. (2007). Postoj společnosti k osobám se zdravotním postižením. (Master's Thesis, Technical University, Liberec, Czech Republic).

Švecová, V. (in press). Problematika sluchového postižení z pohledu vysokoškolských studentů. Olomouc: Univerzita Palackého.

Švecová, V. (2013). Partnerské vztahy očima žáků se sluchovým postižením. In D. Finková, a kol. Iniciačni analýza podmínek inkluze u osob se specifickými potřebami $(63-80)$. Olomouc: Univerzita Palackého.

Švecová, V. (2012). Možnosti pracovniho uplatnění u osob se sluchovým postižením. (Master's Thesis, University Palacky, Olomouc, Czech Republic). Retrieved from http://library.upol.cz/arl-upol/cs/detail-upol_us_cat-0085833-Moznosti-pracovnihouplatneni-u-osob-se-sluchovym-postizenim/?disprec $=1 \&$ iset $=1$.

Uhrová, E. (2013). Partnerské vztahy osob se sluchovým postižením. (Master's Thesis, University Palacky, Olomouc, Czech Republic). Retrieved from http://library.upol.cz/ arl-upol/cs/detail-upol_us_cat-0116151-Partnerske-vztahy-u-osob-se-sluchovympostizenim/?disprec $=2 \&$ iset $=1$.

United Nations (3 March 2015). Convention on the Rights of Persons with Disabilities. Retrieved from http://www.un.org/disabilities/convention/conventionfull.shtml.

Vávrů, M. (2007). Postoj budoucích učitelů k problematice zdravotního postižení. (Master's Thesis, Masaryk University, Brno, Czech Republic). Retrieved from http://is.muni.cz/ th/66248/pedf_m/Diplomova_prace.txt

World Health Organisation (3 March 2015). Deafness and Hearing Loss. Retrieved from http://www.who.int/mediacentre/factsheets/fs300/en/. 